\title{
BIOGAS PRODUCTION AND REMOVAL COD - BOD AND TSS FROM WASTEWATER INDUSTRIAL AICOHOL (VINASSE) BY MODIFIED UASB BIOREACTOR
}

\author{
Isni Utami, Sri Redjeki, Dwi Hery Astuti and Sani \\ University of Pembangunan Nasional "Veteran" Jawa Timur, \\ Surabaya, Indonesia \\ Email: isniutami@yahoo.com
}

\begin{abstract}
Biogas production and decreased organic loading of vinasse using a modified UASB bioreactor has been done successfully. Vinasse is waste from the ethanol industry which contains COD: $9.360 \mathrm{mg} / \mathrm{L}$, BOD : $4.013 \mathrm{mg} / \mathrm{L}$, and TSS: $317.5 \mathrm{mg} / \mathrm{L}$. The purpose of this research was to study the performance of bioreactors Upflow Anaerobic Sludge Blanket (UASB) to decompose the vinasse into biogas or methane. UASB operating principle is to distribute wastewater in the bioreactor to flow upward through the sludge blanket by setting the hidrolic retention time (HRT). Four UASB bioreactor columns were used in this experiment wherein each with a capacity of $50 \mathrm{~L}$ in volume; $23 \mathrm{~cm}$ inside diameter, and $120 \mathrm{~cm}$. The variations of hydraulic capacity followed the variations of HRT in the range of 72-36 hours. Modifications were carried out on the top of column UASB with the aim of preventing gas losses and increasing the flowrate of gas out from the top of the column. The results showed that HRT increased from $36 \mathrm{~h}$ to $72 \mathrm{~h}$ followed by an increase in COD removal efficiency of $55.64 \%$ to $66.81 \%$; BOD $_{5}$ from $67.85 \%$ to $74.58 \%$; and TSS from $66.69 \%$ to $84.19 \%$. The maximum volume of biogas produced was in the range of $5.826 \mathrm{~L} /$ day $(42.89 \%$ methane) to $7.930 \mathrm{~L} /$ day (methane $58.06 \%$ ).
\end{abstract}

Keywords: Biogas, Methane, UASB, Vinasse,

\section{INTRODUCTION}

Vinasse is wastewater from the ethanol fermentation industry which still contains high enough organic matter, so that it can be used as raw material for biogas production. The waste water can be decomposed by microorganism to degrade organic material in a bioreactor. The organic matter parameter, measured as BOD or COD, can be used as a substrate for bacteria (Ashish et al., 2014). Substrate utilization will be able to produce the removal of chemical contaminants (Okpokwasili and Nweke, 2005), forming a new microorganism cells and decomposition product (Schuner and Jarvis, 2009; Vadivel et al., 2014).

Decomposition of organic wastes can be done with the anaerobic system (Guerrero et al., 1999; Driessen and Yspeert, 1999; Liu et al., 2002). Anaerobic wastewater treatment can generate methane gas $\left(\mathrm{CH}_{4}\right)$ and carbon dioxide $\left(\mathrm{CO}_{2}\right)$, which is known as biogas. Biogas is used as an alternative fuel that is environmentally friendly, thus the liquid waste vinasse is utilized commercially. Methane fraction varies depending on the substrate contained in wastewater (Marchaim, 1992) .

Anaerobic degradation of organic compounds can be efficient and stable when there is a balance metabolism rate beetween the acid-forming bacteria and bacteria that form $\mathrm{CH}_{4}$ (Yu and Fang, 2003). Imbalance can occur due to excessive organic loading or changes in operating conditions (Tabatabaei et al., 2011) which would trigger the accumulation of acidic intermediate products that are inhibiting bacteria methanogens (Marchaim, 1991).

According to (Mulligan et al., 1993), the loading of $36.5 \mathrm{~kg} \operatorname{COD} / \mathrm{m}^{3} /$ day can produce gas by $12 \mathrm{~m}^{3} / \mathrm{m}^{3} /$ day.

\section{UASB (Upflow Sludge Blanket Anaerobic)}

UASB is one way of anaerobic wastewater treatment which operated continuously. In the UASB bioreactor, wastewater flowed vertically from the bottom upward through the sludge blanket towards which there is a bacterial decomposition of waste. UASB performance was strongly influenced by Hydrolic Retention Time (HRT); Hydrolic Loading Rate (HLR); Velocity Up (Vup); influent flow; the concentration of organic waste; Organic Load Rate (OLR); and variable operating temperature and degree of acidity $(\mathrm{pH})$ (Alphenar et al., 1993; Aslan and Sekerdag, 2008; Farajzadehha et al., 2012; Ramakrishna et al., 2013).

The anaerobic process using conventional UASB have limitations in processing capacity, due to mass transfer limitations caused by the mixing process, conditions are less than optimal in the reactor (shin et al., 2003).

This process is mostly applied in industrial waste with an organic load of the medium, which has a concentration of COD (Chemical Oxygen Demand) in the range of 3000-7000 mg / L (Lettinga and Hulshoff, 1991).

Long enough HRT will allow longer contact between the anaerobic sludge wastewater so that the process of decomposition of organic substances to be better (Farajzadehha et al., 2012). However, according to Van Haandel (2006), a very long HRT may adversely affect granulation process sludge in UASB bioreactor, while a very short HRT can lead sludge to drift out of its biomass reactor. UASB technology for wastewater treatment has been widely studied with a variety of performance parameters (Van Haandel, 2006; Ramasamy et al., 2004; Supriyanto et al., 2010)). Most of the study were prioritized on the removal of $\mathrm{COD}, \mathrm{BOD}_{5}$ and TSS; while not much has been done for the production of biogas using UASB.

This study aims to assess the performance of a modified UASB reactor for treating vinasse waste into biogas. Modifications was done at the top of the column UASB so that the volume of space above the columns are not too big to prevent gas losing so that gas products formed may soon be out of the reactor. 


\section{METHODOLOGY}

Vinasse waste was obtained from PT Energi Nusantara Agro, Mojokerto, Indonesia. Vinnase analysis showed that the COD: 9,630 mg / L; BOD: 4,013 mg / L; TSS: $317.5 \mathrm{mg} / \mathrm{L}$ and a $\mathrm{pH}$ of 6.5 . Activated sludge was taken from the slurry manure (as methanogenic anaerobic bacteria).

Acclimatization of microbes was performed for five days. To remove oxygen, Nitrogen gas was used. After the acclimatization stage is completed, it was followed by the stage of running for 18 days. Influent $\mathrm{pH}$ is maintained at around 7 by adding $\mathrm{CaO}$. Column-shaped reactor served as a tank anaerob with dimensions of 23 $\mathrm{cm}$ in diameter; $120 \mathrm{~cm}$ in height with a volume of 50L. The volume of sludge was $30 \%$ of the volume of waste. Figure 1 shows a circuit of UASB.

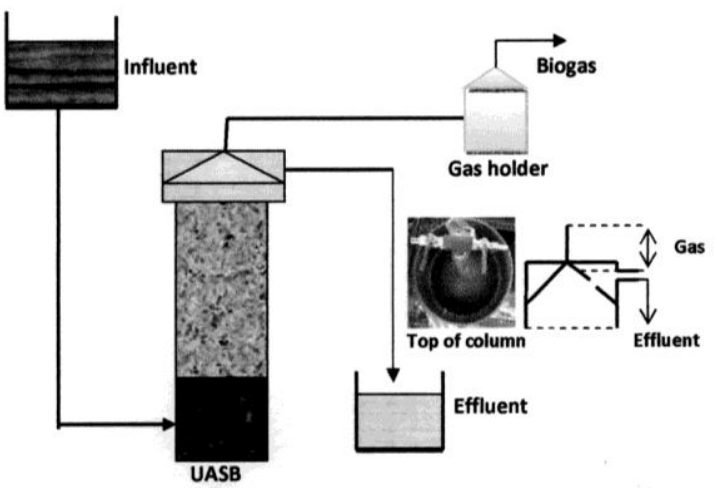

Figure-1. Diagram of UASB Process

Waste water flows into the influent tank and then flowed into the UASB reactor at a predetermined flow rate. Liquid waste flowed from the bottom of the reactor then flows upward through the mud bed anaerobic in which microorganisms sludge in contact with the substrate in wastewater. On the other hand, sludge bed that consists of microorganisms that grow naturally in the form of granules with a diameter of 0.5 to $2 \mathrm{~mm}$ has a high deposition speed so that it can fight the wash out of the system at high hydraulic loads. Anaerobic degradation process will produce gas (biogas containing $\mathrm{CH}_{4}$ and $\mathrm{CO}_{2}$ ), and the movement of gas bubbles being released upwards causing upheaval hydraulic reactor blend naturally without using a mixer. At the top of the reactor, there is a separation of solids, liquids and gases by a three-stage separator (also known separator gas-liquidsolid). Biogas will be captured through the hose, while the liquid effluent will flow into the effluent tank. Discharge arrangement adapted to Hydrolic retention time (detention time) of each reactor is 72 hours, 60 hours, 48 hours and 36 hours with a reactor volume of 50 liters. Table 1 shows the variation of HRT relationship with flowrate, HRL and Vup.

Table-1. Corellations of HRT, flowrate, HRL, and Vup

\begin{tabular}{|c|c|c|c|}
\hline $\begin{array}{c}\text { HRT } \\
\mathrm{h}\end{array}$ & $\begin{array}{c}\text { Flow rate } \\
\mathrm{L} / \mathrm{h}\end{array}$ & $\begin{array}{c}\text { HRL } \\
\mathrm{m}^{3} / \mathrm{m}^{2} / \mathrm{h}\end{array}$ & $\begin{array}{c}\text { Vup } \\
\mathrm{m} / \mathrm{h}\end{array}$ \\
\hline 72 & 0.6944 & 0.0167 & 0.0167 \\
\hline 60 & 0.8333 & 0.02 & 0.02 \\
\hline 48 & 1.0416 & 0.025 & 0.025 \\
\hline 36 & 1.3888 & 0.033 & 0.033 \\
\hline
\end{tabular}

The analysis of characteristics of the waste was carried out by COD analysis using SNI 6989.73-2009 and $\mathrm{BOD}_{5}$ 6989.72-2009. While GC 7900 gas analyzer used the Biogas Porapak Q method (Area ASTD). Gas volume measurements were performed daily, while gas composition analysis was done every 2 days and TSS analysis every 3 days.

\section{RESULT AND DISCUSSION}

Figure 2 shows the correlation of HRT and UASB operation time to the reduction of COD. COD decreased high enough up to twelveth day and then decreased slowly up to the eighteenth days. This trend did not occured on a decrease of BOD in which up to eighteen days it tends to be stable (Figure 3). HRT increase will be followed by a decrease in the concentration of COD and $\mathrm{BOD}_{5}$, it shows that there has been a decomposition of organic material by microorganisms activity.

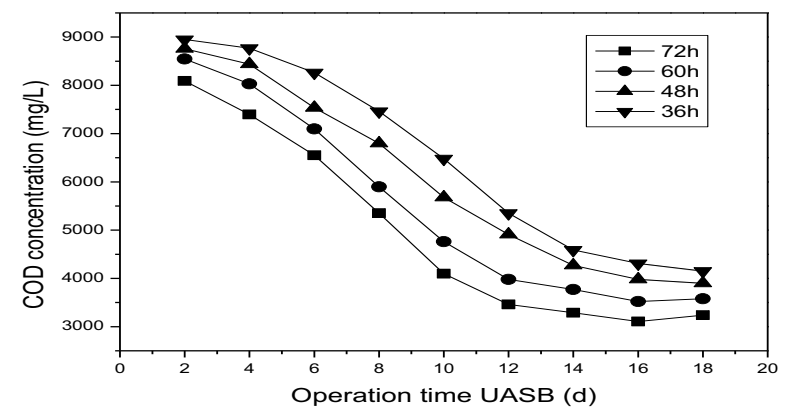

Figure-2. Correlation of HRT and UASB operation time to reduction of COD

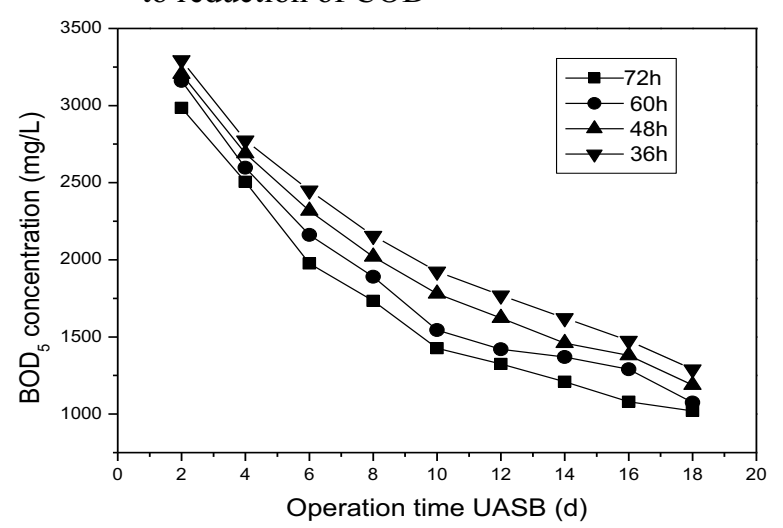

Figure-3. Correlation of HRT and UASB operation time to reduction of $\mathrm{BOD}_{5}$

Increasing the residence time in the reactor means that the longer the waste is in the system. As a result, the contact between the biomass with the substrate is also getting longer so that the process of biological degradation takes place the better, and consequently a reduction in total $\mathrm{COD}$ and $\mathrm{BOD}_{5}$ increased. Organic materials contained in the vinasse are described as complex compounds into the simple compounds. The maximum reduction in $\mathrm{COD}$ and $\mathrm{BOD}_{5}$ obtained for $\mathrm{HRT}$ $72 \mathrm{~h}$, on 16th day of COD concentration reached 3,106 $\mathrm{mg} / \mathrm{L}$ while on 18 th day match $\mathrm{BOD}_{5}$ concentration reached $1,020 \mathrm{mg} / \mathrm{L}$.

Figure 4 showed the effect of HRT and operation time UASB on the percentage removal of $\mathrm{BOD}_{5}$ and COD. The removal of $\mathrm{BOD}_{5}$ is higher than $\mathrm{COD}$ removal both for HRT $72 \mathrm{~h}$ and for HRT $36 \mathrm{~h}$. The removal of 
$\mathrm{BOD}_{5}$ on HRT $72 \mathrm{~h}$ is not much different from the removal of $\mathrm{BOD}_{5}$ at $36 \mathrm{~h}$, but for COD removal is big enough difference between HRT $72 \mathrm{~h}$ and HRT $36 \mathrm{~h}$.

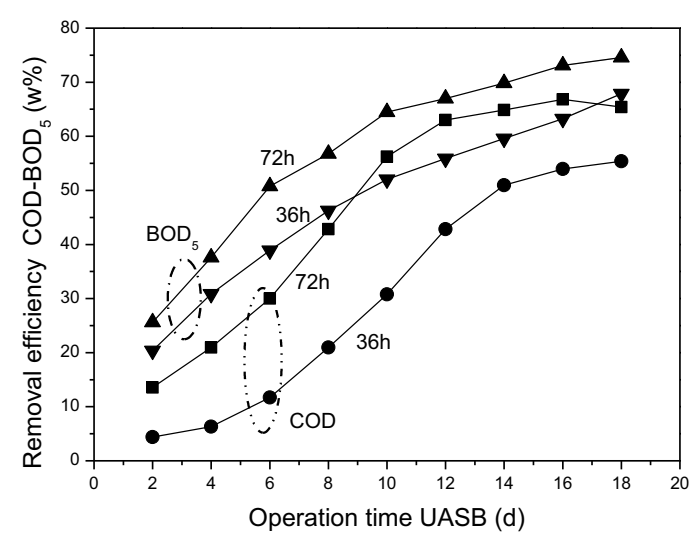

Figure-4. Effect of HRT and UASB operation time on removal efficiency of COD dan $\mathrm{BOD}_{5}$

The maximum COD removal efficiency ranges from $66.81 \%-55.64 \%$ and $\mathrm{BOD}_{5}$ ranges from $74.58 \%$ $68.85 \%$. The largest removal HRT obtained in $72 \mathrm{~h}$ with a percentage removal of $\mathrm{COD}$ of $66.81 \%$ and $\mathrm{BOD}_{5}$ $74.58 \%$. Long enough HRT will provide opportunities for anaerobic sludge and wastewater to contact longer so that the process of decomposition of organic matter becomes better. A longer HRT may adversely affect sludge granulation process in UASB reactor, while a very short HRT can lead biomass to drift out from reactor.

Setting the flow rate of vinnase which flows through the bottom of the reactor is necessary to study its effect on the removal of the organic load (COD and $\mathrm{BOD}_{5}$ ). Variation of the flow rate will also cause the changes on the Hydrolic Loading Rate and upflow velocity (Vup). Table 1 shows the corellations of rate, HRL, and Vup to the removal efficiency of COD and $\mathrm{BOD}_{5}$. The results showed that the greater the flow rate, the greater the HRL and Vup.

Hydrolic Loading Rate (HLR) is a velocity of flow in the reactor, is directly proportional to flow rate and inversely proportional to the cross-sectional area of the reactor. Vup is the flow velocity to pass through the cross section of the UASB bioreactor, is proportional to the flow rate and inversely proportional to the surface area of bioreactor. Operational of Vup on the UASB bioreactor varies according to the flow rate of the bioreactor. Upflow velocity has two opposite effects which can increase the contact time between biomass and substrate, making it possible to eliminate organic matter better. Whereas reducing upflow velocity can interfere with the contact between biomass substrates.

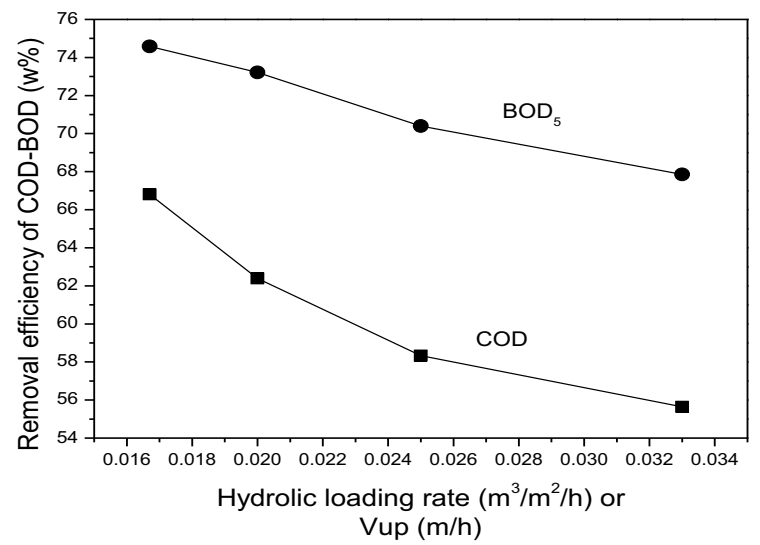

Figure-5. Effect of HLR to the efficiency removal of $\mathrm{COD}$ dan $\mathrm{BOD}_{5}$

The results showed that the smaller the HLR (or Vup) at the same concentration load, COD and $\mathrm{BOD}_{5}$ removal efficiency was increased. The level of efficiency of $\mathrm{COD}$ and $\mathrm{BOD}_{5}$ decreased when the hydraulic and organic loading is increased. Quantitatively, the results obtained by the efficiency of COD and $\mathrm{BOD}_{5}$ largest in HLR $0.0167 \mathrm{~m}^{3} / \mathrm{m}^{2} / \mathrm{h}$ with a percentage of $66.81 \%$ removal of COD and $74.58 \%$ removal of $\mathrm{BOD}_{5}$.

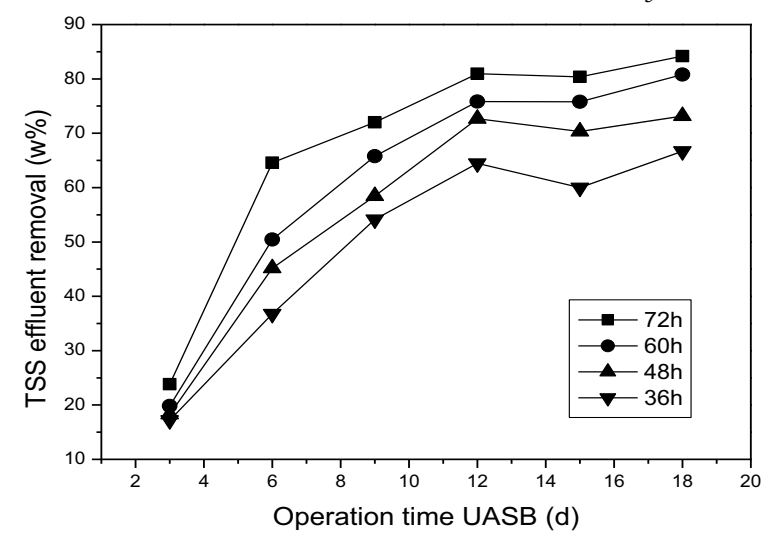

Figure-6. Correlation of HRT and operation time UASB to the efficiency of reduction of TSS consentration

Figure 6 shows the correlation of HRT and operation time UASB to the efficiency of reduction of TSS consentration. Effective time to decompose TSS is 12 days. The results showed that the greater the HRT, the greater the reduction of TSS efficiency and it will be followed by an increase in sludge bed with increasing time. The biggest reduction efficiency of TSS is in the range of 66.69 to $84.19 \%$, and up to a maximum reduction in HRT of $72 \mathrm{~h}$ with a percentage of $84.19 \%$ decreased TSS.

\section{Biogas production}

Figure 7 shows the correlation of $\mathrm{COD}$ and $\mathrm{BOD}_{5}$ reduction on methane volume on $72 \mathrm{~h}$ HRT. COD decreased from about 8,000 to $3,200 \mathrm{mg} / \mathrm{L}$, while the $\mathrm{BOD}_{5}$ decreased from 2,985 to about $1,000 \mathrm{mg} / \mathrm{L}$. On the other hand the volume of methane increased from 0.67 to $4.68 \mathrm{~L} / \mathrm{d}$. It can be indicated that the amount of methane gas that formed more influenced by COD reduction rather than by $\mathrm{BOD}$ reduction. However, the percentage of $\mathrm{BOD}_{5}$ removal $(25.62-74.58 \%)$ is higher than the percentage of COD removal (13.5 - 66.81\%). 


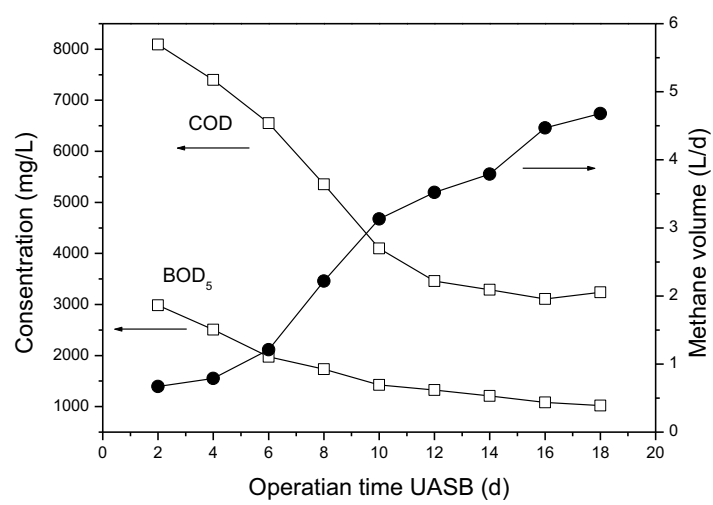

Figure-7. Correlation of $\mathrm{COD}$ and $\mathrm{BOD}_{5}$ reduction on methane volume at $72 \mathrm{~h}$ HRT

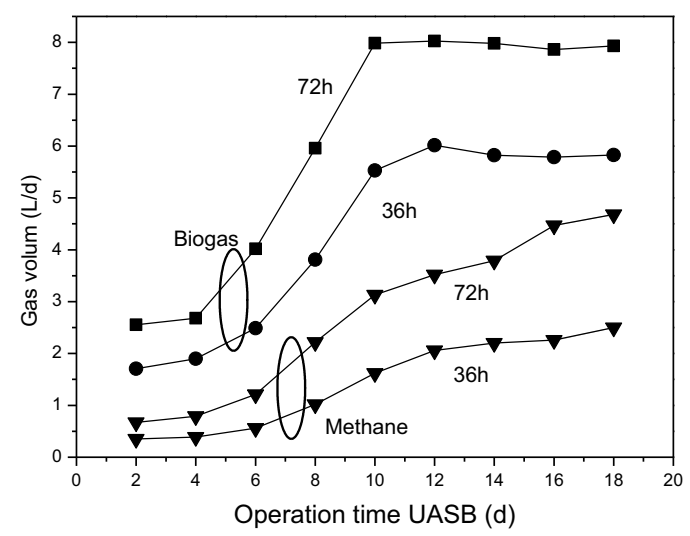

Figure-8. Correlation of HRT and operation time UASB to the production of biogas

Anaerobic degradation process involves a number of different bacteria but the process is driven mainly by two types of reactions, namely acidogenesis and methanogenesis. In the first stage of acidogenic, organic matter is decomposed into VFA (volatile fatty acids), then metabolysis at a later stage by methanogenic bacteria to produce methane gas (biogas). Figure 8 shows the biogas and methane production during fermentation. Biogas production is almost stable after the 10th day at $7.93 \mathrm{~L} / \mathrm{d}$ (72 $\mathrm{h} \mathrm{HRT)}$ and 5.826 (36 h HRT) since the process has reached steady conditions. However, the methane gas production is still slightly increased despite stable biogas condition.

Figure 9 shows the effect of HRT on production of gas on the 18th day. Methane product reached a concentration in the range of 42.89 to $58.06 \%$. Increasing concentrations of methane from HRT $48 \mathrm{~h}$ to $60 \mathrm{~h}$ is considerably higher than of HRT 36 to 48 and from HRT $60 \mathrm{~h}$ to $72 \mathrm{~h}$.

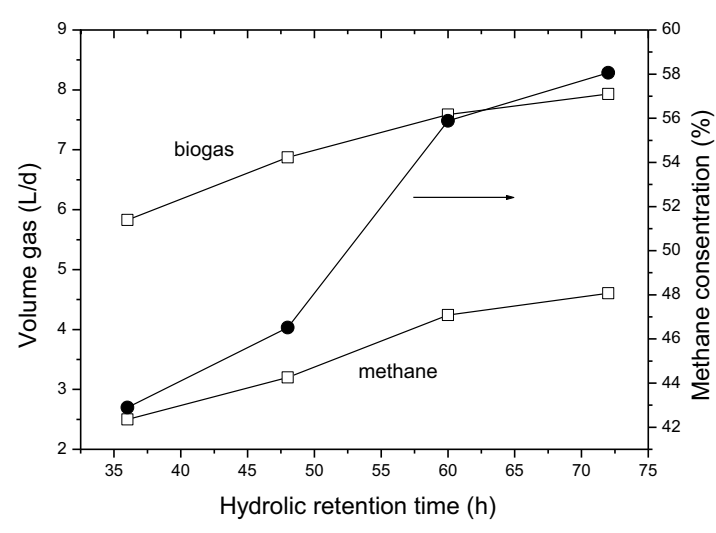

Figure-9. Effect HRT on gas product and methane concentration obtained at the $18^{\text {th }}$ day.

\section{CONCLUSION}

Vinasse can be used as raw material for biogas production. The maximum biogas production at 72 hours obtained biogas volume of $7,930 \mathrm{~L} /$ day with the composition of the gas $58.06 \%$ (4.6042 $\mathrm{L} \mathrm{CH}_{4} /$ day).

$\mathrm{COD} ; \mathrm{BOD}_{5}$; TSS has a relationship with a hydraulic capacity (HRT, debit, VUP, HLR). The smaller the discharge, the smaller Vup / HLR is getting and the higher efficiency, and vice versa. The greater the HRT, the removal of $\mathrm{COD} ; \mathrm{BOD}_{5}$ and TSS increased so that the efficiency of separation is increasing. COD removal efficiency value; $\mathrm{BOD}_{5}$ and TSS optimum occurred in HRT of 72 hours with an organic load of $9360 \mathrm{mg} / 1$ on day 18 which gained $67 \%$ COD removal; $\mathrm{BOD}_{5}$ and TSS $75 \%$ 84.19\%.

\section{REFERENCES}

Ashish,T., Oprakash S., 2014, Study of Characteristics and Treatment of Dairy Industry Wastewater ,J.App \&Environ. Micro, 2 (1),16-22

Aslan, Sibel, Sekerdag, Nusret., 2008, The Performance of UASB Reactors Treating High-Strength Wastewaters. Journal of Environmental Healt,Find Article. Com

Alphenaar, P. A., Visser, A. A., and Lettinga., G., 1993, The Effect of Liquid Upward Velocity and Hydrolic Retention Time on Granulation in UASB Reactors Treating Wastewater with High Sulphate Cotent Biosource Technology, 43, 249.

Driessen, W., and Yspeert, P.,1999. Anaerobic Treatment of Low, Medium and High Strength Effluent in The Agro-Industry. Wat. Sci. Tech., 8, 221-228.

Farajzadehha, Soheil. 2012. Lab Scale Study of HRT and OLR Optimization in UASB Reactor for Pretreating Fortified Wastewater in Various Operational Temperatures. APCBEE Procedia 1, 90-95.

Guerrero, L., Omil, F., Mendez, R., and Lema, J.M., 1999, Anaerobic Hydrolysis and Acidogenesis of Wastewaters from Food Indsutries with High Content of Organic Solids and Protein. Wat. Res., 33, 15, 3281-3290. 
Haandel, A.C., 2006, Anaerobic Reactor Design Concepts for the Treatment of Domestic Wastewater, RevEnviron. Sci.BioTechnol, 5-21.

Liu, H.W., Walter, H.K., Vogt, G.M., Vogt, H.S., Holbein, B.E., 2002, Steam Pressure Disruption of Municipal Solid Waste Enhances Anaerobic Digestion Kinetics and Biogas Yield, Biotechnol. Bioeng. 77, 121129.

Lettinga, G., and Hulshoff pol, L.W., 1991,UASB Process Design for Various Types of Wastewaters. Wat. Sci. Tech., 24, 87-107

Mulligan,C., Bechara,F.S., Meunier,J.et Chebib,J., 1993, Anaerobic Treatment of Cheese Dairy Wastewater Using the SNS Bioreactor. Water Pullutan Reaserch Jaurnal of Canada, 28, 597-619.

Marchaim, U., 1991, Biogas Processes for Sutainable Development.

http://www.citeseerx, ist.tsu.edu/viewdoc/download?doi.

Accessed 17 Juny 2011

Marchaim, U., 1992, Biogas Processes for Sutainable Development.Shmona: MIGAL., Galilee Technological Centre Kiryat Shmona, Israel.

Okpokwasili, G.C., and Nweke, C.O., 2005, Microbial Growth and SubstrateUtilization Kinetic. African Journal of of Biotecnology, 5(4), 305-317.

Ramakrishna Rao, R,S., Bala Prasad,S,B., Sekhar P,S,R., S.A. Rahiman, S,A., 2013, Performance Studies on Wastewater Treatment Efficiency of an Artificial

Wetland, J.Environ Eng \& Techno., 2 (3), 40 - 35

Ramasamy, E.V., Gajalakshmi, S., Sanjeevi, R., Jithes, M.N., Abbasi, S.A., 2004, Feassibility Studies on the Treatment of Daiary Wastewater with Upflow Anaerobic Sludge Blanket Reaktors. Bioresource Technology, 93, 2009-212.

Soepriyanto, Tantowi,I., Murtina, D. L. and Bernadeta, N., 2010, Vinase Processing of Alcohol Industry Wastewater into Biogas Using UASB Bioreaktor, Journal Purifikasi, 11 (1), 11-20

Schnurer, A., and Jarvis, A., 2009, Microbiological Handbook for Biogas Plants http://www.ocfarmbiogas.ca/Microbiological $\% 20$

Handbook\%20for\%Biogas\%20PIants,pdf.

Shin, H.S., Han, S.K., Song, Y.C., dan Lee, C.Y., 2001, Performance of UASB Reactor Treating Leachate from Acidogenic Fermenter in the Two-phase Anaerobic Digestion of Food Waste. Wat. Res., 35, 3441-3447.

Tabatabaei, M., Sulaiman, A.M., Nikbakht, N., Yusof, Najafpour, 2011, Influential parameter on Biomethane
Generation in Aerobic Wastewater Treatments Plants. Accessed 4 October 2011

Vadivel, R Minhas, P.S, Kumar, P. Singh, Y., Nageshwar, R., Nirmale, A., 2014, Significance of vinasse waste management, Afr.J.Agric.Res., 9 (38), 2862-2873.

Yu, H.Q., and Fang, H.H.P., 2003, Acidogenesis og Gelatin - Rich Wastewater in an Upflow Anaerobic Reaktor:Influence of $\mathrm{pH}$ and Temperature.Water Research 37(1), 55-56. 